\section{THE NATIONAL HEALTH SERVICE ACT 1946}

By S. R. Speller, Ll.B. Pp. xc + 497. London : H. K. Lewis. 1948. £22s.

This book consists of a collecting together in one volume the complete National Health Service Act, 1946, with its ten schedules, together with all the statutory instruments in full up to the date of publication in July 1948 . There is appended a list of other statutes still in force that apply to the present National Health Service.

It is, of course, of value to have collected into one volume all the provisions of the National Health Service Act and the statutory instruments for convenience of reference, but much of the value of this volume lies in the index, permitting quick reference to appropriate sections to be made ; this should be very helpful to all concerned with the operation of the National Health Service. Without this volume it would be necessary to keep a large number of official publications to hand, and, when any problem arose necessitating reference to these, a prolonged search might have to be made to make sure that no official provision was being overlooked. The author apologizes for not having had time to make the index, especially from the point of view of cross references, as complete as he wished ; doubtless, in subsequent editions, he will achieve an even finer index.

The whole Act and its statutory instruments in one volume impresses the non-administrative medical man with the vast bureaucratic edifice which a nationalized health service has built up, and must make him fear that progress and elasticity may become increasingly enmeshed in this increasing growth. The voluntary hospitals have been criticized since the passing of the Act for their allegedly inadequate and unsystematic accountkeeping, but if the reward for a certain incompleteness here was the vigour and speedy progressiveness of these institutions, then the criticism was unjustified.

Unconscious humour and humanity can be found even in a volume of this official character. One must smile, on turning through the pages, to find disproportionately lengthy provisions applying to the Isles of Scilly, with their population, I believe, of only about two thousand. Would it not be a good thing for the future of our society if the whole of Great Britain were broken up into many scores of little Isles of Scilly, with their local variations and differing individualities?

A glance at these official regulations, concentrated into one valuable volume, must impress one with the danger of a rigid over-centralization of administration, with only token devolution to the peri- phery. Developments since the publication of this volume only increase this natural fear. Let us hope, for the future of medicine and the hospitals that Parliament, in the not-too-distant future, makes it necessary for $\mathrm{Mr}$. Speller to produces with equal efficiency and industry a completely revised and very different edition of this book.

\section{DISORDERS OF THE BLOOD}

By Sir Lionel Whitby, C.V.O., M.C., M.A. M.D., F.R.C.P., D.P.H., and C. J. C. BRITTON,M.D., D.P.H. 6th Edition. Pp. xii +759 , witho ro6 illustrations, 12 in colour. London: J. \& A. Churchill Ltd. I950. $42 \mathrm{~s}$.

A new edition of Whitby and Britton's well 으 known textbook is a welcome event, and the practising haematologist is hardly likely to be disz appointed with the sixth edition recently published In size the present volume is $\mathbf{8 5}$ pages bigger then its predecessor. Revision has been thorough and remarkably complete; few recent papers of ifi - portance published up to the end of 1949 have begnco

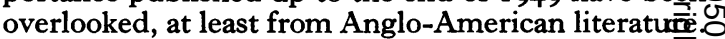
Particularly good are the accounts of recent wati in the fields of iron metabolism, the haemorrhagico disorders and the effects of radiation on the blood, and the newer therapeutic agents such as Vitamino $\mathrm{B}_{12}$, radiophosphorus and aminopterin receive theirô share of space.

It is naturally possible in a book as large as this to find some points for mild criticism. The ' colour index,' for instance; surely this has outlived its usefulness and does not merit the attention it re ceives. The space thus saved might be usefully: given to a much more detailed account of the important subject of the errors of red cell counting and the calculation of ' absolute' values.

A few points on transfusion technique also call for comment; it is stated (page $3 \mathrm{II}$ ) that "great careo must be taken to cross-match (blood) properly (in $\beta$ cases of acute idiopathic haemolytic anaemia) soo that the transfused cells are incapable of adsorbing any circulating haemolysin '-this is indeed $a$ difficult task. On the following page there is alsoa slip-the indirect instead of the direct technique of ${ }_{O}$ Coombs is mentioned as the method for detecting sensitization of the patient's own red cells. OnO page 379 it is surely wrong to say that "thew phenomenon of haemagglutination . . . is inevitablyo followed by haemolysis,' and on page 587 to refero to the antibody which gives the Donath-Land- $\frac{\tau}{0}$ steiner cold hae nolysis reaction as a cold agglutinines? (on page 314 this is correctly referred to as a haemolysin). 
In a consideration of the direct matching test before blond transfusion (page 694) the use of albumin is referred to, but the very valuable Coombs' technique is not mentioned. Indeed, it is not quite clear what test is recommended and in what circumstances. The general advice, however, that the work should, wherever possible, be undertaken in a properly-equipped laboratory by an experienced person is clearly sound.

The above criticisms can only be considered as minor blemishes in a work of this size. Without question, the authors are to be congratulated on having carried out a revision of so large a field.

$$
\text { J.V.D. }
$$

\section{OPHTHALMIC MEDICINE}

By J. H. Doggart, M.A., M.D., F.R.C.S. Pp. x +329 ; with 87 illustrations, many in colour. London: J. and A. Churchill. 1949. 32s.

The common ground of ophthalmology and general medical disorders has been adequately explored by few writers and the need for a successor to Foster Moore's classic work has been keenly felt for some time. Mr. Doggart has set out to fill this need and the result is an eminently readable little book of some 35 chapters, pleasantly produced and liberally illustrated.

Space is devoted to ophthalmological manifestations of general infections, disorders of the throat, nose and ear, skin diseases, metabolic, cardiovascular blood and renal disorders and the student may find here a reference, of necessity brief, to the chief ocular manifestations of such diseases. Four excellent introductory chapters deal with ophthalmic symptomatology and methods of examination and these include a particularly well-illustrated section on physical signs, whilst a chapter on the significance of refractive errors has wisely been given a central position in the book. Later chapters deal with the broad relationships of neurological and ophthalmological disorder, congenital abnormalities and the effects of drugs and poisons.

For the physician in training and the physician in practice the book will be found a useful addition to his library.

\section{H.E.H.}

\section{STUDIES ON TUMOUR FORMATION}

By the late G. W. DE P. Nicholson. Pp. $x+637$, with 184 illustrations. London: Butterworth \& Co. 1950. $£ 33$ s.

This volume is a beautifully produced reprint of the late G. W. Nicholson's 20 Studies on Tumour Formation which appeared in Guy's Hospital Reports between 1922 and I938. To Nicholson's contemporaries and students these studies need no commendation, and their reappearance in this compact form will be very welcome. To pathologists of a younger generation, it affords a ready access to the principal works of one of their greatest predecessors, a master of his subject who was not widely enough appreciated in his own lifetime. The 3 Studies cover a wide range-the general structure $\stackrel{\circ}{\circ}$ of tumours, hamartomas and other minor mal- $C$. formations, heterotopia of tissues, metaplasia, $\overrightarrow{\vec{F}}$ endometriosis, mixed tumours and teratomas. On $\stackrel{\mathscr{S}}{\stackrel{9}{ }}$ all of these subjects Nicholson wrote with great 0 originality, with a stronger basis in general biology than any other writer, with arresting and amusing $\frac{\bar{\omega}}{5}$ criticisms of ill-founded hypotheses, and with $\mathbb{\Phi}$ apposite quotations from the classics. In his exposures of the falsity of the hypotheses of Cohn- $ळ$ heim on ' cell rests,' of Grawitz on renal tumours $\vec{\circ}$ and of Wilms on teratomas, he was far ahead of most of his contemporaries and indeed of many $\vec{\omega}$ writers of today, who would do well to read him $\stackrel{\circ}{\circ}$ now. Besides containing a wealth of factual infor- 8 mation, Nicholson's Studies are thought-provoking 3 . and piquant, the utterances not only of a great is pathologist, but of a great philosopher and a great biologist. For this reason his work will continue $\mathcal{O}$ to be of permanent interest as a landmark in the history of the subject.

Nicholson's 184 illustrations, most of them micro- is scopical pen-and-ink drawings executed by his own hand, are reproduced here. The original $\frac{}{2}$ blocks and drawings were not available, so that $\vec{r}$ the pictures had to be reproduced from the printed $z$ page; the publishers are to be congratulated on the care they have taken to ensure well-nigh perfect 3 reproductions. A full index adds greatly to the $\mathbb{D}$ value of the book, and a glance over this at ong reveals the great range of subjects covered in th $\vec{\oplus}$ 20 Studies.

This volume will be valued, not only "for the wealth of information it contains, but also because it is a worthy memorial to a great pathologist. Guy's Hospital staff, by agreeing to the republication of Nicholson's work in this handy form, have not only fittingly honoured his memory but have also done a signal service to pathology.

\section{R.A.W.}

\section{POSTGRADUATE OBSTETRICS AND GYNAECOLOGY, $195^{\circ}$}

By F. J. Browne, M.D., D.Sc., F.R.C.S.Ed., F.R.C.O.G. Pp. vi +544 , with I07 illustrations. London: Butterworth \& Co., Ltd. 1950. 50s.

This book is largely based upon the author's celebrated postgraduate courses given in recent years at the Soho Hospital for Women, and is written chiefly for those seeking to specialize in obstetrics and gynaecology. In no sense is it a complete textbook, but is a collection of studies selected widely though not altogether at random of from subjects of major practical importance. It $N$ will make a great appeal to ex-Servicemen and to those who, by the lapse of time since their qualifying examinations, have lost touch with advances and current thought; only a great and experienced teacher could have achieved the remarkable blending of fundamentals with up-to-date embellishments with such economy of words and yet such fluent literary style. 